\title{
Graphene Phytotoxicity in the Seedling Stage of Cabbage, Tomato, Red Spinach and Lettuce
}

\author{
Bunshi Fugetsu and Parvin Begum \\ Laboratory of Environmental Medical Chemistry \\ Graduate School of Environmental Science \\ Hokkaido University \\ Japan
}

\section{Introduction}

The use of nanostructures with unusual novel properties in agriculture (Joseph, 2006) and for technological applications has been an active and exciting area of research in recent years. Graphene, the most recently discovered carbon allotrope, is a two-dimensional building block of atomic thickness that can be stacked into three-dimensional graphite, rolled into one-dimensional nanotubes, or wrapped into zero-dimensional fullerenes (Geim \& Novoselov, 2007). The unique electronic and transport properties of graphene (Ando, 2009), compatible with existing manufacturing processes (Xia et al., 2009), and the absence of the energy gap in the electronic spectra have opened up increasingly rich possibilities in the development of future electronic devices (Geim \& Novoselov, 2007; Enderlein, 2010) and the graphene-based quantum electronics (Dragoman, 2009) that offer many benefits. If these trends in nanotechnology continue, graphene may ultimately be released into the aquatic, terrestrial, and atmospheric environments, where its fate and behavior are largely unknown. Exposure to nanoparticles in higher plants is expected to have an effect because these plants strongly interact with their atmospheric environments (Monica, 2009). The nanoparticles, with their ultra-small size, specific shape, geometric structure, and unique properties, may have the potential for increased toxicity (Bhabra, 2009; Kirchner et al., 2005; Nowack \& Bucheli, 2007; Jia et al., 2005). Nanoparticles can drastically modify their physico-chemical properties compared to particles of bulk size (Nel et al., 2006). Carbon nanoparticles can penetrate plant cells (Lui et al., 2009; Khodakovskaya et al., 2011) and induce phytotoxicity at high doses (Stampoulis et al., 2009; Ghodake et al., 2010; D.H. Lin \& Xing, 2007), leading some authors to conclude that certain carbon nanoparticles are not $100 \%$ safe. Therefore, great caution is suggested when considering the introduction of nanoparticle-based products to the market, and there is an urgent need for research related to the broad area of nanotoxicology. A recent study, for example, has pointed to the possible adverse effects of graphene on human health (Zhang et al., 2010) and in bacteria (Akhavan \& Ghaderi, 2010). In response to these concerns, we explored whether graphene can induce phytotoxicity at high doses in terrestrial plants grown hydroponically and exposed to varying concentrations ( 0 to $2000 \mathrm{mg} / \mathrm{L}$ ) of graphene. Thus far, only one study has evaluated the 
toxic effect of graphene on plant physiology and plant development, indicating possible adverse effects (Khodakovskaya et al., 2011). Khodakovskaya et al., (2011) reported insignificant toxicity of graphene in the growth of tomato, although they used only one low concentration $(50 \mu \mathrm{g} / \mathrm{mL})$ of chemically functionalized graphene with few layers and with a thickness of 2-5 nm. In a study by Says et al., (2006) carbon nanoparticle functionalization led to a remarkable decline in toxic effects. The effects of nanoparticles on different plant species can vary greatly with plant growth stages and method and duration of exposure and depend also on nanoparticle size, concentration, chemical composition, surface structure, solubility, shape, and aggregation (Nel et al., 2006).

Thus, to our knowledge, the possible adverse effects of graphene in terrestrial plants is almost totally unknown. Here, we use cabbage, tomato, red spinach, and lettuce as the selected crops to investigate the toxic effects of graphene and to identify appropriate target plant species for further studies associated with graphene. Potential targets include various terrestrial plants that are normally protected by specific barriers such as a cell wall. Targeting can be made more effective by prolonged exposure of different plant species to carbon nanoparticles and application of a high concentration, which can lead to aggregation on the root surface (C. Lin et al., 2009), penetration within the cells (Khodakovskaya et al., 2011), and a contribution to toxic effects (Stampoulis et al., 2009; Ghodake et al., 2010; S. Lin et al., 2009). This report is the first to describe the phytotoxic effect of graphene in terms of seedling growth, cell death, reactive oxygen species (ROS) generation, and morphology change. Our results showed the greatest toxic effect of graphene on cabbage and tomato, followed by red spinach, with no clear toxic effect for lettuce.

\section{Results and discussion}

A previous study uncovered evidence supporting that carbon-based nanoparticles have adverse effects on terrestrial plants (D.H. Lin \& Xing, 2007) opening the way to further investigation. Consequently, we assessed the potential impact of graphene on the growth of tomato, cabbage, red spinach, and lettuce based on tests suggested and encoded by USEPA guidelines (USEPA, 1996), which include consideration of studies on seed germination and seedling growth (root and shoot growth, leaf number), often accompanied by other evaluations of cell death, ROS production, and morphological studies using scanning electron microscopy (SEM), useful for obtaining evidence of in situ symptoms of possible toxicity. Altogether, the current work investigating the potential effect of graphene demonstrates possible adverse effects on plants, underscoring the need for ecologically responsible disposal of graphene and for more research on the potential effects of graphene on agricultural and environmental systems.

\subsection{Graphene analysis}

Water-soluble graphene, commonly referred as graphene oxide with sodium ions as the counterions (solution $\mathrm{pH}$ 6.32), was used throughout this study. Atomic force microscopy (AFM) was used to evaluate the morphologies of the graphene; Figure 1 shows typical AFM images. The apparent heights of all the graphene observed were found to be around $1 \mathrm{~nm}$, indicating that the graphene was fully exfoliated into individual sheets with the size of length $\times$ breadth ranged from $0.5 \times 0.6 \sim 1.5 \times 6.5 \mu \mathrm{m}$ for 30 pieces of the graphene. Figure 2 A shows typical SEM image of the graphene, revealing the morphology of the graphene sheets. Figure 2 B shows a transmission electron microscope (TEM) image of the graphene, 
Graphene Phytotoxicity in the Seedling Stage of Cabbage,

which exhibits a typical wrinkled structure (Stankovich et al., 2006) with the corrugation and scrolling that are fundamental to graphene (Meyer et al., 2007).

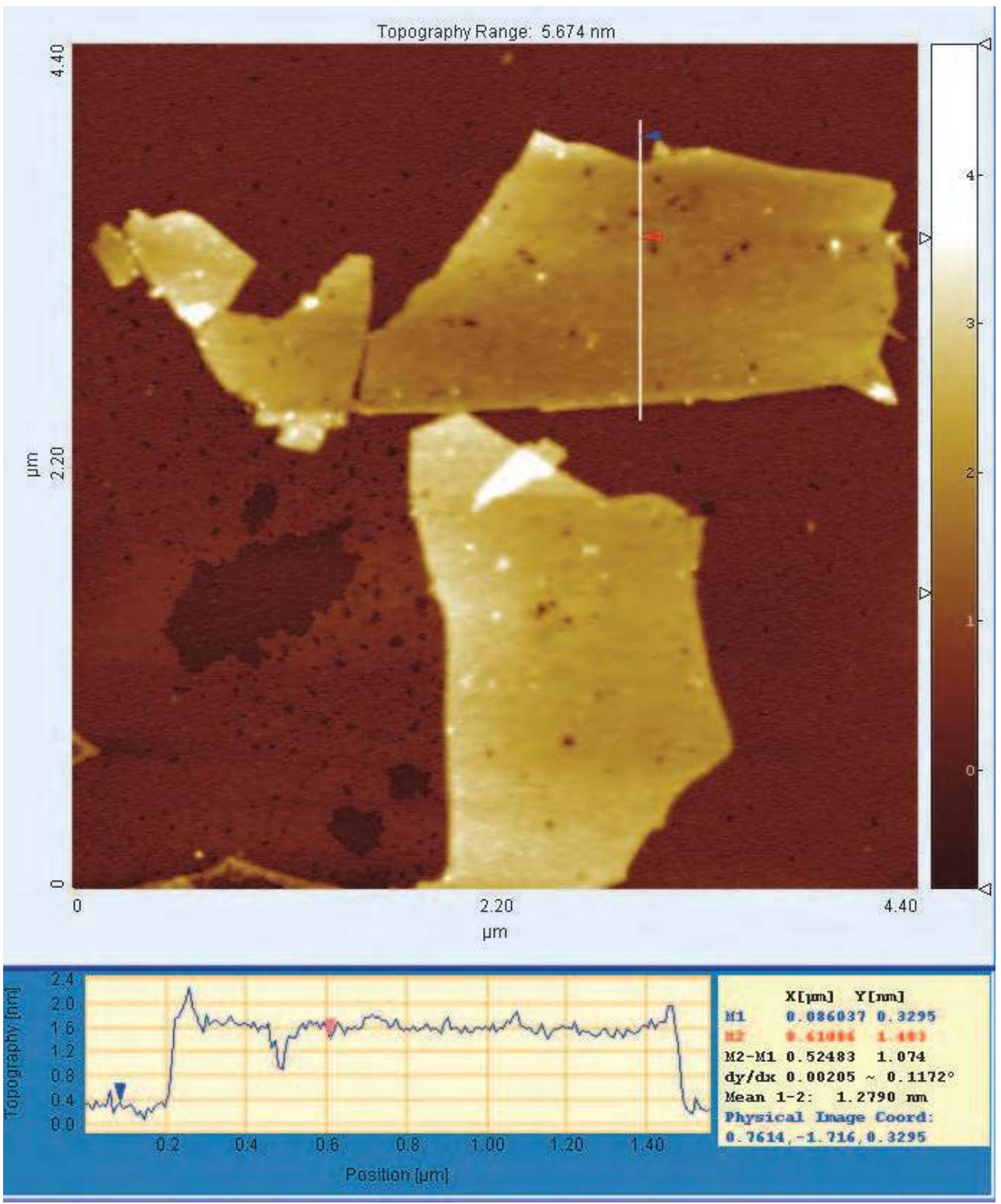

Fig. 1. AFM image of graphene. 


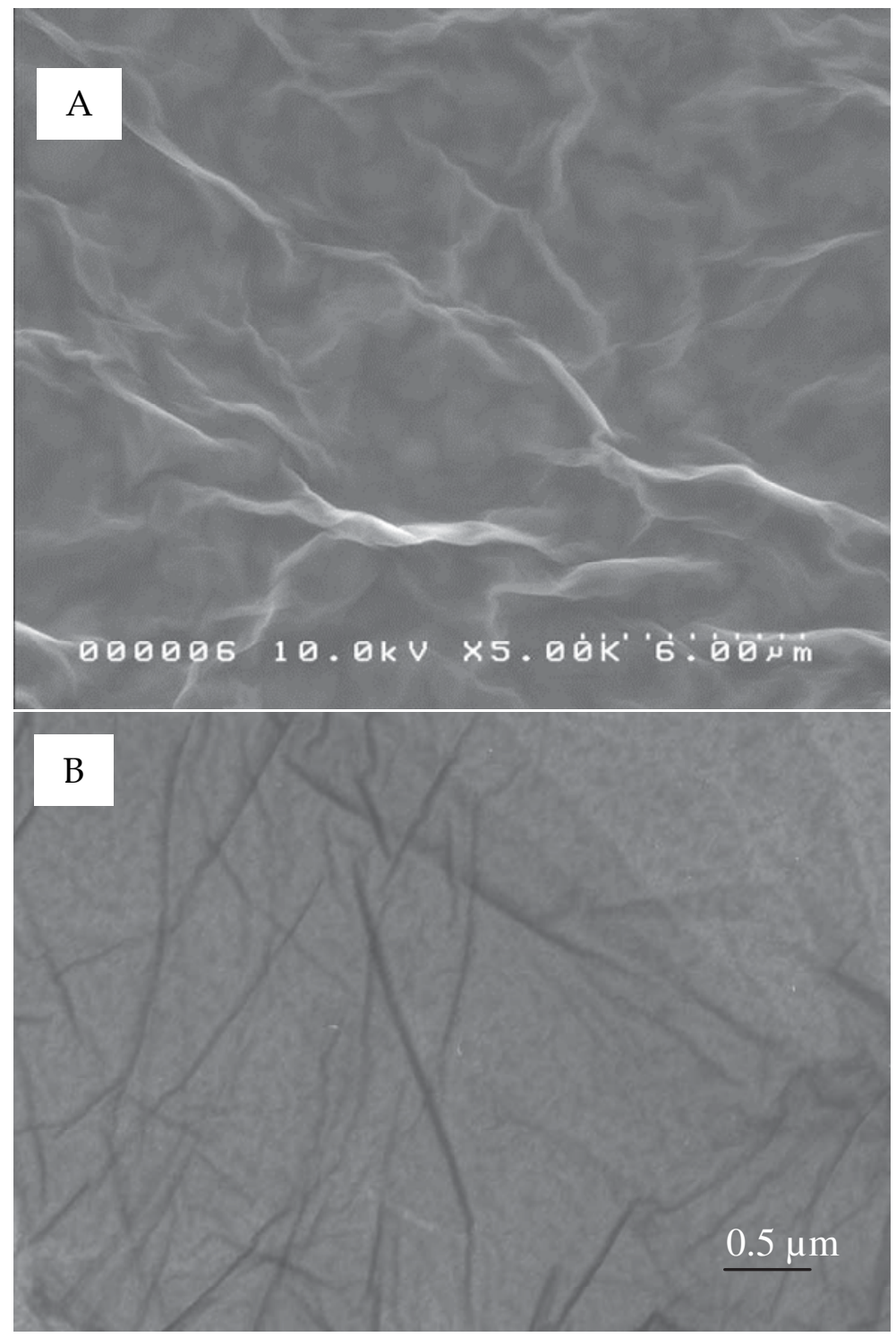

Fig. 2. (A) SEM image and (B) TEM image of graphene.

\subsection{Graphene repression of plant growth}

We conducted a series of tests of the potential effect of graphene on the growth of tomato, cabbage, red spinach, and lettuce. Treated and untreated seeds were germinated after 4 days of incubation at $25{ }^{\circ} \mathrm{C}$ in the dark. Fully germinated seedlings with developed cotyledons and root system are shown in Figure 3. Cotyledons and root system were retarded with increasing graphene concentration. Only in the case of lettuce was there no significant 
influence of graphene on the cotyledons and root system after 4 days (data not shown). On the other hand, graphene had a clear negative influence after 20 days on root and shoot length and biomass of tomato, cabbage and red spinach exposed to graphene. The observed influence depended on the concentration of graphene and the duration of the experiment. In hydroponics experiments, when plants were treated with different concentrations of graphene $(0,500,1000$, and $2000 \mathrm{mg} / \mathrm{L})$, the 20-day-old plants were characterized by inhibition of plant growth and leaf number and leaf size decrease with increasing graphene concentration in comparison with control (Figure 4) and showed toxicity symptoms. No significant effect of graphene on the parameters tested (seed germination and growth) was noted in our experiment in the case of lettuce. Therefore, the following discussion is focused on the results obtained for the other three plants.

(A)

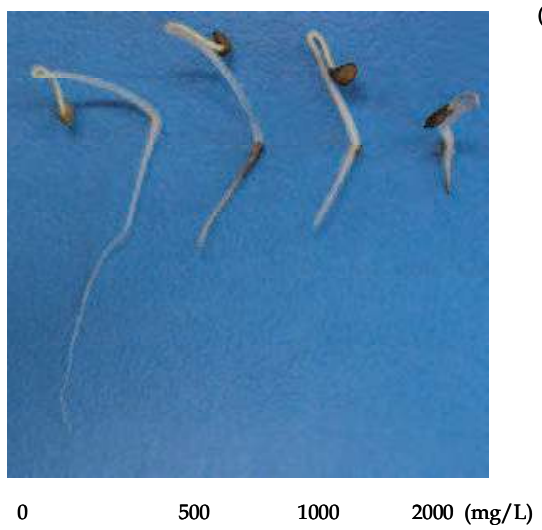

Concentration of $\mathrm{G}$ in growth medium
(B)

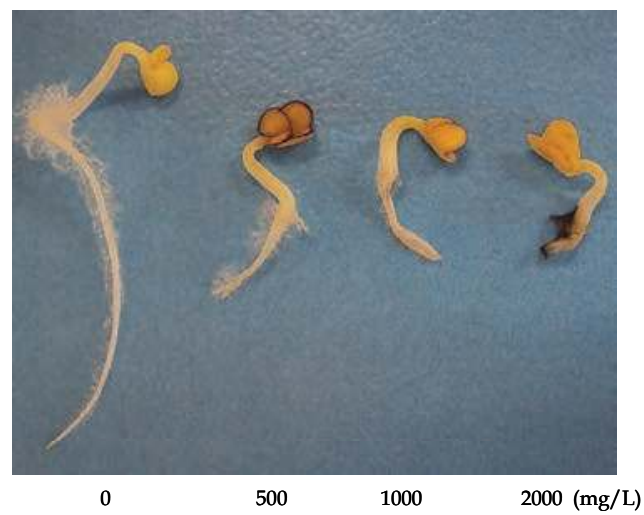

Concentration of $\mathrm{G}$ in growth medium

(C)

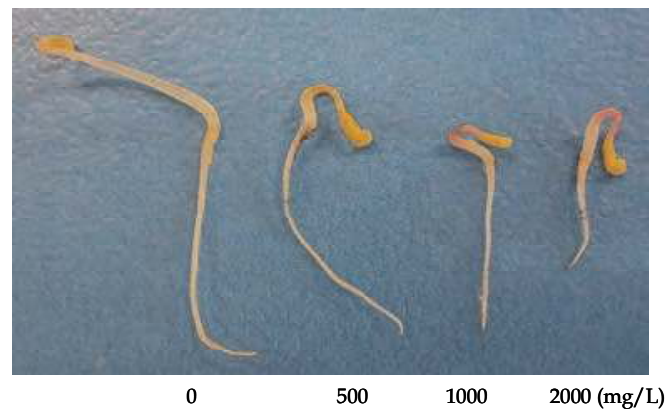

Concentration of $\mathrm{G}$ in growth medium

Fig. 3. Graphene (G) affected cotyledons and root systems. (A-C) Tomato, cabbage, and red spinach seeds after incubation with and without graphene solution on filter paper for 4 days, respectively. 
(A)

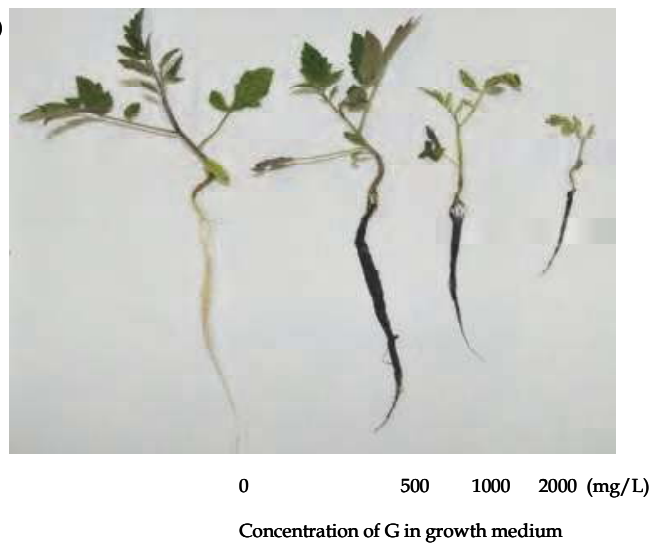

(B)

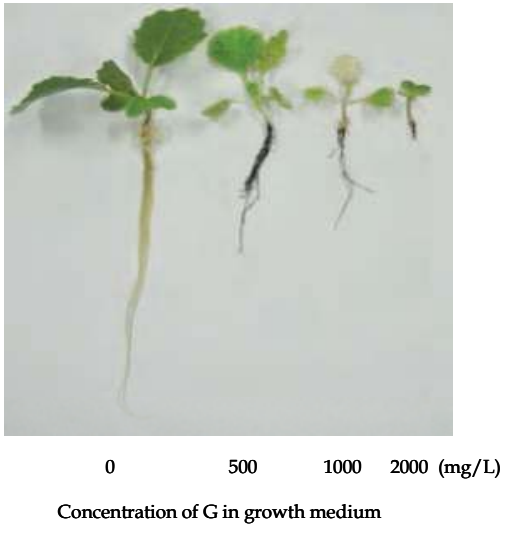

(C)

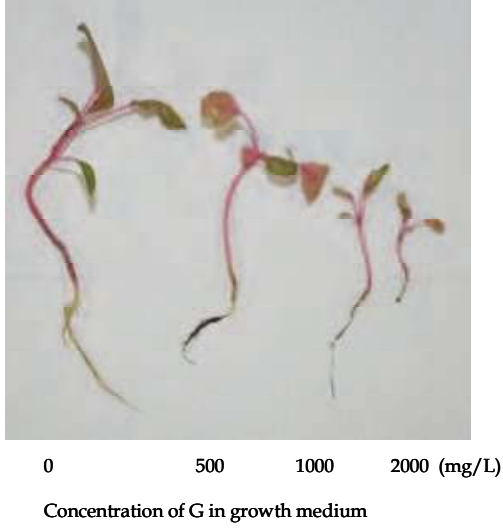

Fig. 4. Effect of graphene $(G)$ on growth and development of cabbage, tomato, and red spinach seedlings. (A-C) Tomato, cabbage, and red spinach seedlings were hydroponically grown in Hoagland media for 20 days with and without graphene, respectively.

The presence of graphene resulted in decreased root and shoot growth (Figure 5A, B). However, graphene at a lower concentration $(500 \mathrm{mg} / \mathrm{L})$ resulted in only a slight decrease in root and shoot length. A marked inhibition effect was observed with the highest concentration of graphene $(2000 \mathrm{mg} / \mathrm{L})$. In the case of cabbage, there was a significant increase in root and shoot growth inhibition greater than $78 \%$ and $61 \%$, respectively, compared to control. The $2000 \mathrm{mg} / \mathrm{L}$ concentration graphene resulted in root and shoot growth inhibition of tomato of $46 \%$ and $53 \%$, respectively, compared to control. Inhibition of shoot growth was noted in red spinach $(13 \%)$ at $500 \mathrm{mg} / \mathrm{L}$, and the highest concentration $(2000 \mathrm{mg} / \mathrm{L})$ resulted in further significant inhibition of shoot growth (39\%). However, no significant effect of graphene on the root growth of red spinach at $500 \mathrm{mg} / \mathrm{L}$ was observed while root growth of red spinach was inhibited by $18 \%$ at the higher graphene concentrations (1000 and $2000 \mathrm{mg} / \mathrm{L}$ ).

The presence of graphene resulted in decreased root and shoot weight (Figure 5C, D). With cabbage seedlings grown in hydroponic culture, the root and shoot weight was sensitive to 

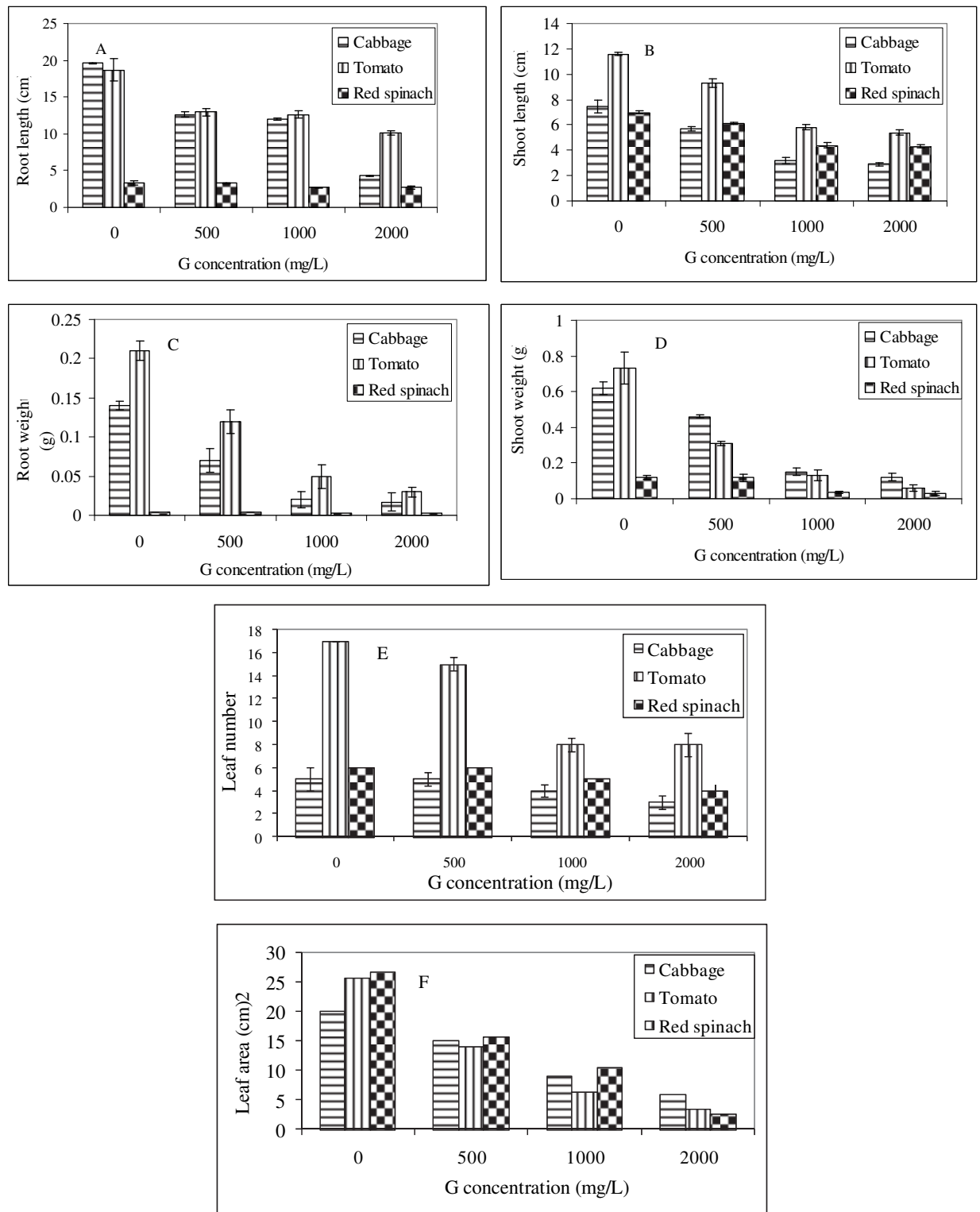

Fig. 5. Effect of graphene $(G)$ on growth and development of cabbage, tomato, and red spinach seedlings. Twenty-day-old seedlings growing on Hoagland media with graphene $(0,500,1000$, and $2000 \mathrm{mg} / \mathrm{L})$ were used for all measurements. Error bars represent standard deviation. (A) Root length, (B) shoot length, (C) root weight, (D) shoot weight, (E) leaf number, and (F) leaf area. 
graphene, and weight decreased by $88 \%$ and $81 \%$, respectively, at the highest concentration (2000 mg/L) compared to control. The root and shoot weight of tomato was also sensitive to graphene, and weight decreased by $86 \%$ and $92 \%$, respectively, at the highest concentration (2000 mg/L) compared to control. With red spinach, the shoot weight appeared to be more sensitive to graphene compared to root; the root and shoot weight of red spinach decreased by $39 \%$ and $75 \%$ at the highest concentration $(2000 \mathrm{mg} / \mathrm{L})$, respectively, compared to control. Tomato seedlings were somewhat more sensitive to graphene than were cabbage and red spinach seedlings.

Graphene influenced the leaves of all tested plants in a dose-dependent manner (Figure 5E). The number of leaves decreased with increasing graphene concentration compared with control. For example, control tomato without graphene developed an average of 17 leaves each, whereas the treated tomato developed only 8 leaves each at 1000 and $2000 \mathrm{mg} / \mathrm{L}$ (Figure 5E). The leaf numbers of the treated plants were considerably decreased by $40 \%$, $53 \%$, and $33 \%$ at the highest graphene concentration $(2000 \mathrm{mg} / \mathrm{L})$ in cabbage, tomato, and red spinach, respectively. The leaves exhibited reduced size and wilting symptoms, as evidenced by visual observation (Figure 4). Of interest, the leaf area (visual observation, Figure 4, Figure 5F) of all treated plants was gradually reduced and continued to decline with increasing graphene concentration. A significantly reduced leaf area of the treated plants was clearly observed at the highest graphene concentration ( $2000 \mathrm{mg} / \mathrm{L}$, Figure 5F) compared to control. Furthermore, the leaf area of cabbage was reduced by $25 \%$ at 500 $\mathrm{mg} / \mathrm{L}$ and by $71 \%$ at $2000 \mathrm{mg} / \mathrm{L}$ compared to control, indicating a dose-dependent reduction. Tomato had an $88 \%$ leaf area reduction at $2000 \mathrm{mg} / \mathrm{L}$ (Figure $5 \mathrm{~F}$ ) and $45 \%$ at 500 $\mathrm{mg} / \mathrm{L}$. The leaf area of red spinach was reduced by $91 \%$ at $2000 \mathrm{mg} / \mathrm{L}$ compared to control (Figure 5F).

We found that cotyledons and the root system of cabbage, tomato, and red spinach were inhibited after four days and observed further inhibition in seedling growth at different graphene concentrations. Although $500 \mathrm{mg} / \mathrm{L}$ graphene had a slight effect, $2000 \mathrm{mg} / \mathrm{L}$ resulted in a notable effect on the seedling stage of cabbage, tomato, and red spinach. By comparison, graphene at $50 \mu \mathrm{g} / \mathrm{mL}$ increased growth rates with no sign of significant toxicity for tomato in the seedling stage (Khodakovskaya et al., 2011). Khodakovskaya et al., (2011) investigated the effect of four carbon materials (single-, multiwall CNTs, few-layer graphene materials, and activated carbon) on the seedling stage of tomato at $50 \mu \mathrm{g} / \mathrm{mL}$. As noted, a high concentration of graphene was not employed in that study, and the authors used only one low concentration. Under such low-concentration conditions, metals play an essential role in the development of plants at the limit of plant tolerance. If an excess of metals is absorbed by plants, toxic effects can manifest, including growth reduction and abnormalities in cell division (Stiles, 1961), possibly because of the excess metals acting as cofactors for enzymes involved in the formation of intermediate metabolites.

\subsection{ROS measurement and hydrogen peroxide $\left(\mathrm{H}_{2} \mathrm{O}_{2}\right)$ detection}

Plants continuously produce ROS as byproducts of various metabolic pathways, but the excess accumulation of ROS leads to oxidative stress and cell death (Apel \& Hirt, 2004; Wen et al., 2008). ROS products, whether inside or outside the cell, can be key factors in the toxicological effects of nanostructure materials (Nel et al., 2006). CNTs are known to have phytotoxic effects in plant cells because of aggregation (C. Lin et al., 2009) causing cell death and accumulated ROS in a dose-dependent manner (Tan et al., 2009). Graphene may have 
the ability to generate ROS production, based on the similarities of some of the properties of graphene sheets and CNTs. Based on the assumption that graphene can be involved in ROS production in the leaf, we tested this possibility using 20-day-old leaves from test plants for the detection of ROS by means of the ROS-sensitive dye 2',7'-dichlorofluorescein diacetate (DCFH-DA).

We evaluated ROS production (oxidative stress) by means of $\mathrm{H}_{2} \mathrm{O}_{2}$ detection after infiltration with DCFH-DA of treated and untreated leaves. The accumulation of $\mathrm{H}_{2} \mathrm{O}_{2}$ was visualized under a microscope; it can be imaged under fluorescence microscopy after removal of DCFH-DA from the leaves by washing with PBS buffer (Figure 6A-F). Figure panels $6 \mathrm{~B}, 6 \mathrm{D}$, and $5 \mathrm{~F}$ illustrate that graphene-treated leaves showed an increase in $\mathrm{DCFH}$ fluorescence compared to control leaves (Figure 6A, C, and E) of cabbage, tomato, and red spinach, respectively. Measurement of DCFH fluorescence by spectrofluorometer demonstrated the dose-dependent increase in ROS content in graphene-treated leaves (Figure 6G) compared to control. The accumulation of ROS in the leaf was measured with the excitation wavelength at $485 \mathrm{~nm}$ and emission wavelength at $522 \mathrm{~nm}$. As Figure 6G shows, as the concentration of graphene in medium increased, a progressively enhanced DCFH response was observed, strongly suggesting that graphene can cause an oxidative stress reaction in plant cells.

As Figure 6G shows, in the case of red spinach, graphene and our control without graphene shared a similar fluorescence intensity, specificallyat the low graphene concentration (500 $\mathrm{mg} / \mathrm{L}$ ). This finding supports that a low concentration of graphene is not responsible for induction of ROS because metals play an essential role in the development of plants at the limit of plant tolerance. In contrast, graphene at a high concentration elicited a sharply increased ROS level compared to control.

We further tested the excess presence of ROS induced by graphene in 20-day-old leaves of cabbage, tomato, and red spinach by means of the ROS-sensitive dye 3,3'-diaminobenzidine (DAB). Infiltration of leaves with $\mathrm{DAB}$ allowed the detection of $\mathrm{H}_{2} \mathrm{O}_{2}$. The location of insoluble deep radish brown polymerization product produced when DAB reacts with $\mathrm{H}_{2} \mathrm{O}_{2}$ was visualized under a light microscope; it can be imaged after removal of chlorophyll from the leaves by boiling for $15 \mathrm{~min}$ in ethanol. Imaging of deep radish brown polymerization can be considered to indicate the accumulation of $\mathrm{H}_{2} \mathrm{O}_{2}$ (Figure $7 \mathrm{~B}, \mathrm{D}$, and $\mathrm{F}$ ) in cabbage, tomato, and red spinach, respectively, and formation of $\mathrm{H}_{2} \mathrm{O}_{2}$ would be expected as a result of the graphene induction. In control leaf (Figure 7A, C, and E) of cabbage, tomato, and red spinach, respectively, no distinctive deep radish brown polymerization of $\mathrm{H}_{2} \mathrm{O}_{2}$ was detectable. The plants exposed to concentrations of $1000 \mathrm{mg} / \mathrm{L}$ showed significant toxicity after 20 days, with the DAB assay indicating increasing ROS. The amount of formazan formation in leaves was determined at $A_{700}$. As shown in Figure 7G, higher levels of graphene $(1000 \mathrm{mg} / \mathrm{L})$ triggered production of more ROS. The excess ROS production at $1000 \mathrm{mg} / \mathrm{L}$ may be indicative of concentration-dependent ROS generation.

ROS production estimated by DCFH-DA was correlated to an increase in ROS predictable by $\mathrm{DAB}$ assays. However, the results of both assays demonstrated the direct presence of ROS that are produced inside the leaf in those plants grown with graphene. The ROS localization using DCFH-DA and DAB described above was also supported by the quantitative determinations of $\mathrm{DCFH}$ and deep brown polymerization at a higher concentration of graphene (1000 mg/L) (Figure 6G and Figure 7G). These findings are in agreement with those of Zhang et al., (2010) who exposed neural pheochromocytoma- 


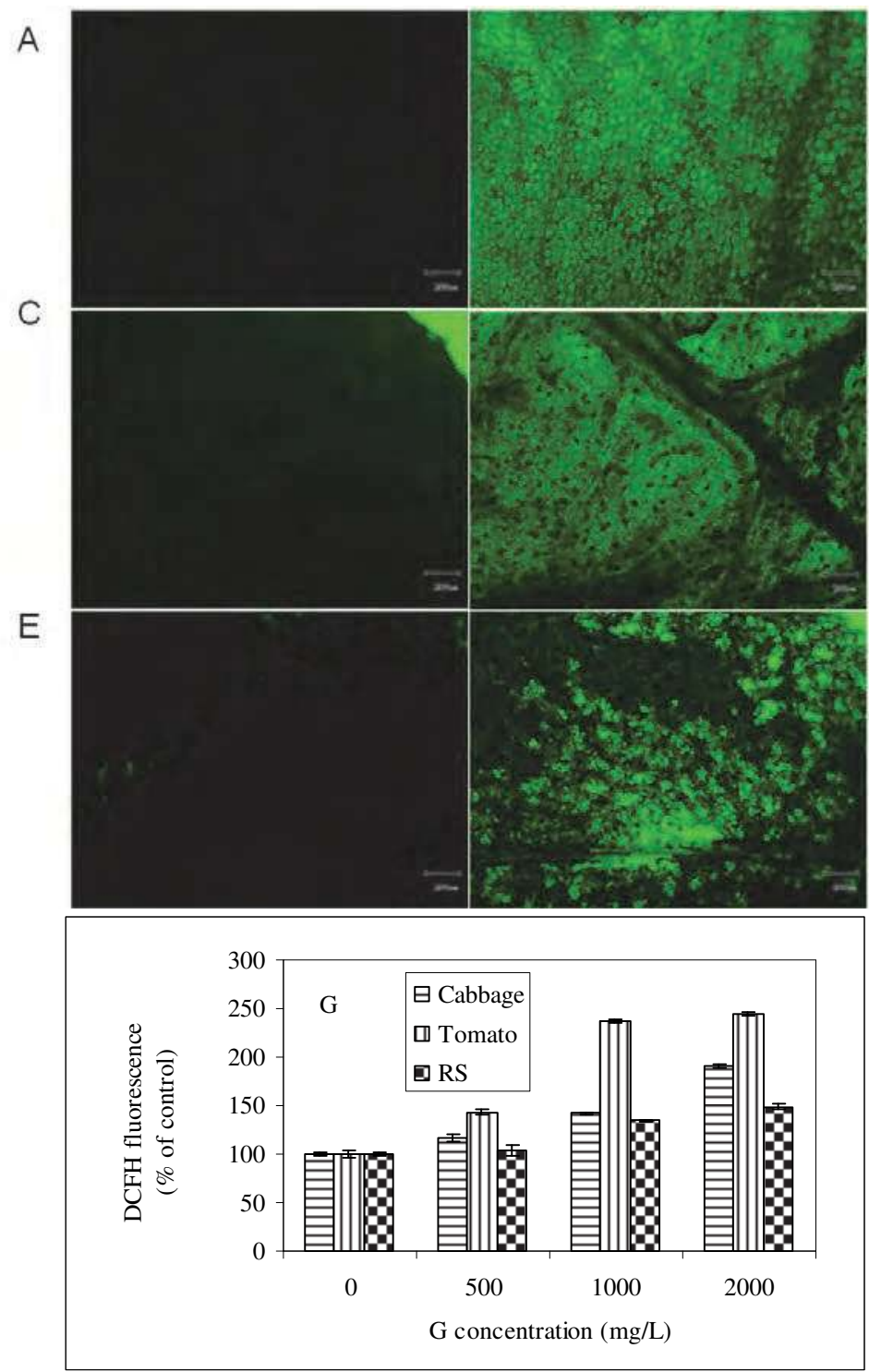

Fig. 6. Effect of graphene $(\mathrm{G})$ on the generation of ROS in leaves tested by means of the ROSsensitive dye DCFH-DA in cabbage, tomato, and red spinach seedlings. Twenty-day-old leaves treated with or without $1000 \mathrm{mg} / \mathrm{L}$ graphene were used for all measurements. Images were observed with fluorescence microscopy. Left lane (A), (C), and (E) cabbage, tomato, and red spinach leaves without graphene. Right lane (B), (D), and (F) cabbage, tomato, and red spinach leaves with graphene $(1000 \mathrm{mg} / \mathrm{L})$. The green signal indicates ROS generation (DCFH fluorescence) in the graphene-treated leaves. $(\mathrm{G})$ Dose-related effects of graphene on ROS in treated leaves measured by DCFH fluorescence. 

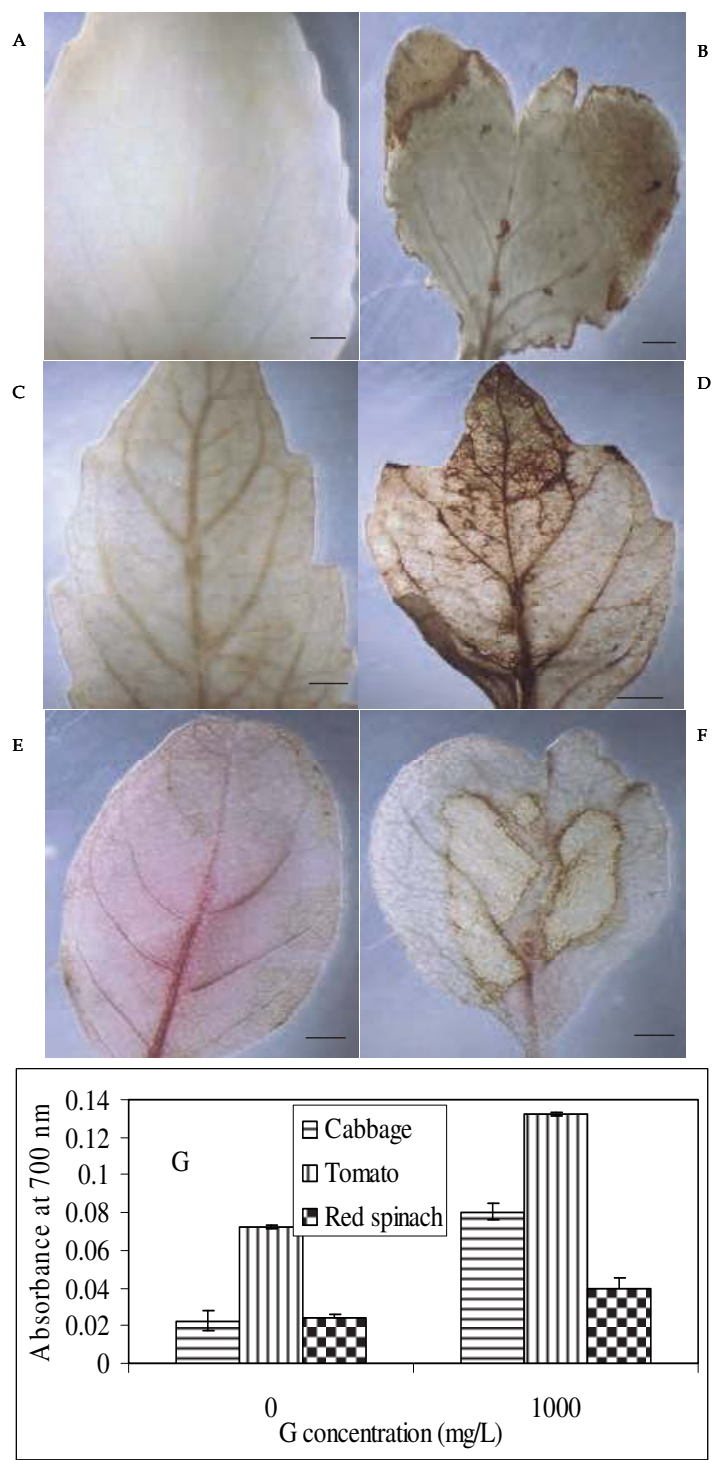

Fig. 7. Effect of graphene $(\mathrm{G})$ on accumulation of $\mathrm{H}_{2} \mathrm{O}_{2}$ in leaves tested by means of the ROSsensitive dye DAB of cabbage, tomato, and red spinach seedlings. Twenty-day-old leaves treated with or without $1000 \mathrm{mg} / \mathrm{L}$ graphene were used for all measurements. Left lane (A), (C), and (E) cabbage, tomato, and red spinach leaves without graphene, respectively. Right lane (B), (D), and (F) cabbage, tomato, and red spinach leaves with graphene $(1000 \mathrm{mg} / \mathrm{L})$, respectively. The brown staining indicates the formation of a brown polymerization product when $\mathrm{H}_{2} \mathrm{O}_{2}$ reacts with DAB. $(\mathrm{G})$ Effect of graphene $(1000 \mathrm{mg} / \mathrm{L})$ on accumulation of $\mathrm{H}_{2} \mathrm{O}_{2}$ in treated leaves as measured using DAB. 
derived PC12 cells to graphene and demonstrated that graphene-induced ROS were involved in the toxic mechanism. It has been reported that ROS are key signaling molecules and could be induced by many exogenous stimuli (Apel and Hirt, 2004).

Evidence for the accumulation of ROS induced by graphene includes the fact that the ability of graphene to reduce plant growth was positively correlated with both the generation of ROS and the graphene concentration (dose-dependent ROS production as estimated by DCFH-DA). Control plants that were devoid of graphene-produced ROS and consequently had not generated ROS did not show a reduction in growth. In the presence of a high graphene concentration in which the content of the nanoparticles exceeds the limit of plant tolerance, ROS may be over-generated, thereby decreasing plant growth. Thus, at least part of the toxic effects of graphene nanoparticles in plants likely results from an excess of induced ROS.

\subsection{Evaluation of cell death}

To evaluate the toxicity of graphene through cell membrane damage in vivo in hydroponic culture conditions, we used a cell death assay. The roots of treated and untreated seedlings were examined by measuring cell death using Evans blue staining and with O.D. values at $597 \mathrm{~nm}$ after a 20 -day exposure to different concentrations $(0,500,1000$, and $2000 \mathrm{mg} / \mathrm{L})$ of graphene. The measurement of the Evans blue extracted from roots showed a concentrationdependent induction (Figure 8A). With the concentration of graphene increasing to 1000 and $2000 \mathrm{mg} / \mathrm{L}$ in the case of cabbage, the amount of Evans blue uptake in root cells increased by about 5 and 12.3 fold, respectively, compared to that of control roots. A significant level of Evans blue uptake was observed after both 1000 and $2000 \mathrm{mg} / \mathrm{L}$ of graphene treatment of tomato roots, representing 11.5 and 14.4 fold, respectively, of that in control roots. The higher concentrations of graphene (1000 and $2000 \mathrm{mg} / \mathrm{L})$ caused 8.5- and 11.8-fold higher uptake, respectively, of Evans blue in roots of red spinach compared to that in control roots. Thus, these results indicate that the loss of plasma membrane integrity occurred with exposure to graphene, as it was greater than in the control plants. Higher (1000 and 2000 $\mathrm{mg} / \mathrm{L}$ ) graphene concentrations caused severe stress on plant growth, inducing the excess generation of ROS. The effects of the ROS may be reflected in the rapid rise of Evans blue uptake. The toxic effect on plant roots appeared after exposure to the lower concentration of graphene, and differences between controls and graphene-treated plants became even more prominent at higher concentrations of graphene, as observed under a light microscope (data not shown).

We analyzed another cell death index to further demonstrate that graphene causes cell membrane damage (electrolyte leakage/plasma membrane sensitivity) in the treated leaf. Electrolyte leakage experiments indicated that the leaves of the graphene-treated plants had decreased membrane integrity (Figure 8B). For these experiments, we used 20-day-old seedlings with leaves, investigating the effect of increasing concentrations of graphene on membrane integrity. Cell membrane damage was noted at $500 \mathrm{mg} / \mathrm{L}$ in cabbage, tomato, and red spinach, and 1000 and $2000 \mathrm{mg} / \mathrm{L}$ resulted in further damage, indicating dosedependent membrane integrity and disruption of the plasma membrane. In addition, as shown in Figure 8B, the results of the electrolyte leakage experiments indicated that the tomato had significantly greater leakage at the highest concentration $(2000 \mathrm{mg} / \mathrm{L})$ compared to cabbage and red spinach. A comparison of Figure 8A and 8B shows that enhancement of Evans blue uptake and loss of plasma membrane integrity gradually increased up to 2000 $\mathrm{mg} / \mathrm{L}$ graphene under the same conditions. Evans blue staining showed that extensive cell 
death/membrane injury was induced in plant roots by different concentrations of graphene treatment. The electrolyte leakage assay confirmed the membrane injury resulting from graphene treatment. This result indicates that the loss of plasma membrane integrity was induced by graphene at the lower concentration and continued at higher concentrations. These results also suggest that intracellular ROS might have a crucial role in induction of cell death induced by graphene. It has been reported that the accumulation of ROS causes cell death, which is demonstrated by electrolyte leakage from cells (Kawai-Yamada et al., 2004).
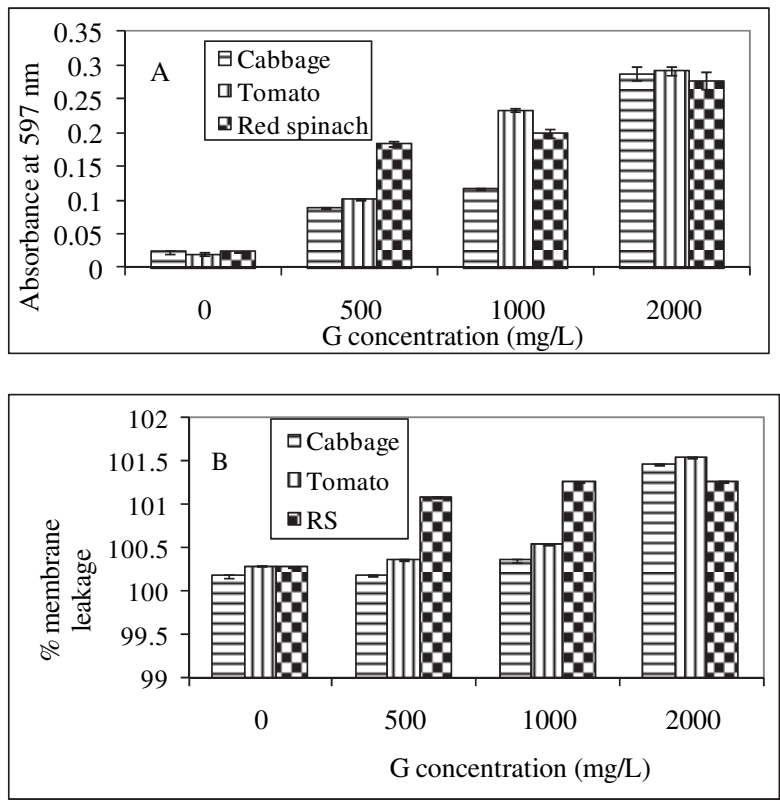

Fig. 8. Effect of graphene $(\mathrm{G})$ on cell death of cabbage, tomato, and red spinach seedlings. Twenty-day-old seedlings growing on Hoagland media with graphene $(0,500,1000$, and $2000 \mathrm{mg} / \mathrm{L}$ ) were used for all measurements. Error bars represent standard deviation. (A) Cell death determined by Evans blue and (B) cell death determined by electrolyte leakage.

The effect of graphene on cell death was evaluated by Evans blue staining and a conductivity method ( $\%$ of membrane leakage). These two assays have been considered as indexes of cell death in plants (Del \& Lam, 1998), although they give information only about plasma membrane integrity. The Evans blue assay is based on the accumulation of blue color inside dead cells (but not in living cells). The conductivity assay is based on electrolyte leakage from dying cells, with ion leakage used as a marker of cell death.

\subsection{Morphological observation by SEM}

To provide clues to graphene toxicity in the seedling stage of terrestrial plant roots, we next visualized the morphological alteration of cabbage, tomato, and red spinach using SEM of the treated roots and compared them to untreated controls (Figures 9, 10, and 11) respectively. SEM examination of the tested plants exposed to a higher concentration of graphene $(1000 \mathrm{mg} / \mathrm{L})$ revealed several morphological alterations compared to the control 
plants grown in Hoagland medium. At 20 days without exposure to graphene, the majority of the root surface appeared healthy; little to no alteration in morphology was observed. Regarding morphology at $1000 \mathrm{mg} / \mathrm{L}$ of graphene, root shape changed especially above the elongation area of cabbage and tomato (Figure 9 and 10) respectively. compared to control. Epidermis of the treated tomato (Figure 10B, C, E, and F) and red spinach (Figure 11B, D, and E) root was loosely detached or even completely detached compared to control, which was characteristic for membrane damage as determined by Evans blue. We note that specific differences could be observed after Evans blue staining at the light microscopic level (data not shown) with respect to the cell morphology between roots exposed to different concentrations of graphene. Thus, differences in cell death determined from Evans blue assays do reflect the sensitivity of cells to different concentrations of graphene, although the morphological alterations observed from light microscopy indicate a common cell death pathway. These results imply that the root membrane with a higher graphene concentration $(1000 \mathrm{mg} / \mathrm{L})$ had no tolerance to graphene stress. An aggregation of graphene was noted on the surface of the root of cabbage, tomato, and red spinach, indicating that aggregation of graphene contributes at least in part to its toxic properties, as is the case for CNTs (C. Lin et al., 2009).

The root surface area of the graphene-treated cabbage was obviously different from the untreated control (Figure 9). The root surface area of cabbage was significantly increased by graphene treatment, and it may be that an excess of graphene resulted in swelling. This observation is similar to results previously reported for Origanum vulgare by PanouFilotheou \& Bosabalidis (2004) and in cowpea by Kopittke et al., (2007). At a higher graphene concentration $(1000 \mathrm{mg} / \mathrm{L})$, the root hair growth of cabbage and red spinach was decreased compared to control.

The two forms of carbon nanoparticles, CNTs and graphene, have similar chemical composition and crystalline structure. Based on this fact, a reasonable inference is that the two would be similar in many ways, such as biological activity. But they are different in shape; CNTs are tubular while graphene is flat atomic sheets (Lui et al., 2009). As a result, atomically flat graphene nanostructures have been estimated to have an even stronger interaction with biological systems than the tubular-shaped CNTs. There is evidence that CNTs could translocate to systemic sites (roots, leaves, and fruits) and engage in a strong interaction with the cells of tomato seedlings, resulting in significant changes in total gene expression in roots, leaves, and fruits (Khodakovskaya et al., 2011) and exerting toxic effects (Stampoulis et al., 2009; Ghodake et al., 2010; S. Lin et al., 2009). CNTs are also known to have phytotoxic effects in plant cells because of aggregation (C. Lin et al., 2009), causing cell death and accumulated ROS in a dose-dependent manner (Tan et al., 2009). Considering these aspects, it is not unexpected to find toxic effects of graphene on terrestrial plant species, as we did in tomato, cabbage, and red spinach in the current study. Oxidative stress has been regarded as a suitable mechanism for explaining the toxicity of graphene.

The phytotoxicity of graphene is likely the result of its ability to generate ROS as represented predominantly by hydrogen peroxide $\left(\mathrm{H}_{2} \mathrm{O}_{2}\right)$ using the ROS-sensitive dyes DCFH-DA and DAB. Reports regarding graphene-induced oxidative stress are available (C. Lin et al., 2009). Concerning the relationship between graphene-mediated ROS generation and cell death in plants, we investigated physiological and morphological endpoints, including visual symptoms, ROS production, SEM observation, and cell death-related responses after exposure to graphene for 20 days. Graphene-treated leaves showed significant accumulation of $\mathrm{H}_{2} \mathrm{O}_{2}$ compared with control (Figure 6). This observation was 
closely associated with visible signs of necrotic damage lesions (Figure 4), cellular ROS accumulation monitored by DAB (Figure 7), and membrane damage (Figure 8B). The evidence of massive cell death (electrolyte leakage assay) as well as visual signs (Figure 4 and Figure 7) with the graphene-treated leaves demonstrated that at 20 days following exposure to graphene, necrosis was the predominant death response in treated leaf cells. In addition, the spatial pattern of $\mathrm{H}_{2} \mathrm{O}_{2}$ production was mainly located in the close proximity of visible symptomatic areas and the sites undergoing cell death.

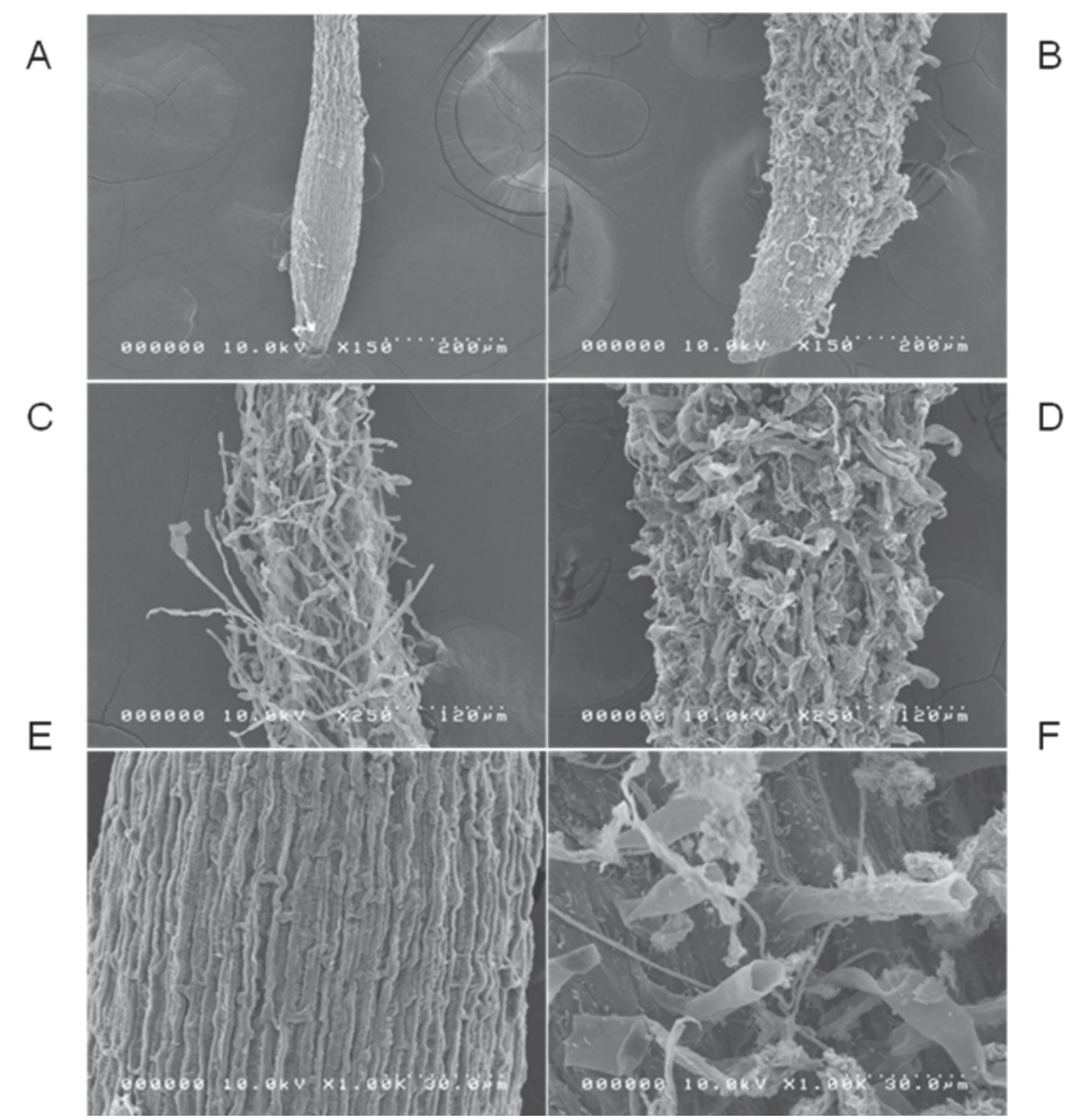

Fig. 9. Behavior of graphene $(1000 \mathrm{mg} / \mathrm{L})$ on the root surface of cabbage seedlings grown in Hoagland medium. (A, C, E) SEM image of the untreated control of cabbage root elongation, root hair zone and surface respectively. (B, D, F) SEM image of the G treated cabbage root elongation, root hair zone and surface respectively showing aggregates of $\mathrm{G}$. 
A

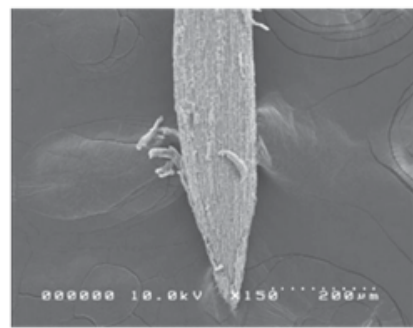

B
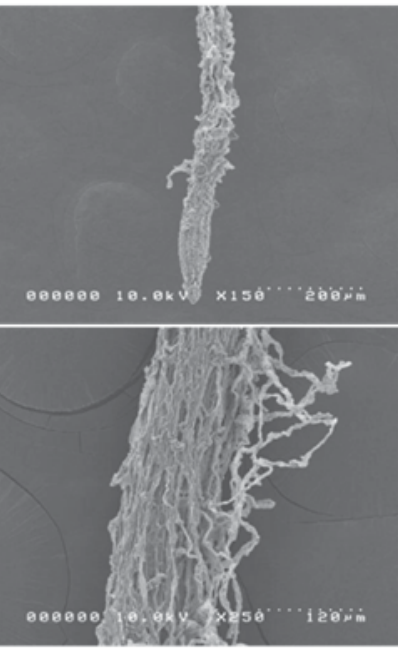

E
C

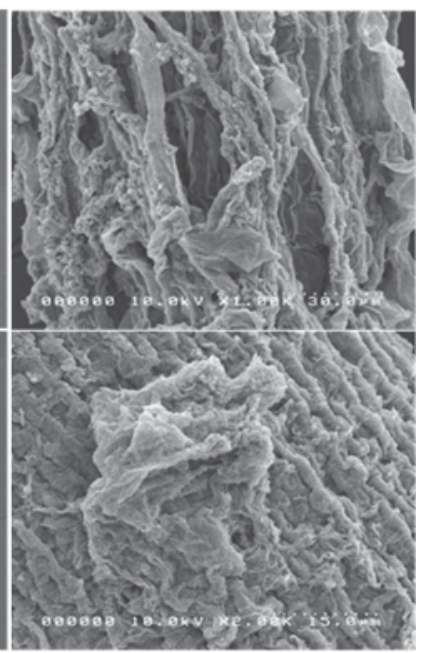

$\mathrm{F}$

Fig. 10. Behavior of graphene $(1000 \mathrm{mg} / \mathrm{L})$ on the root surface of tomato seedlings grown in Hoagland medium. (A, D) SEM image of the untreated control of tomato root elongation and root hair zone respectively. (B) Root elongation zone of tomato root and (C, E, F) showing surface detachment and aggregates of $\mathrm{G}$ on the tomato roots surface treated with $\mathrm{G}$.

Plant cell death occurs either by apoptosis or by necrosis. Necrosis is passive and characterized by a progressive loss of membrane integrity that results in cytoplasmic swelling and release of cellular constituents (Van Breusegem \& Dat, 2006). Furthermore, we also detected the effect of graphene on the morphology of roots, finding that the epidermis of the treated tomato and red spinach roots was only loosely detached or even completely detached. Further, the aggregation of graphene was noted on the surface of the roots of all graphene $(1000 \mathrm{mg} / \mathrm{L})$-treated plants, indicating that aggregation of graphene contributed at least in part to its toxic properties, as is the case for CNTs (C. Lin et al., 2009). On the basis of these results, we infer that graphene phytotoxicity involved the oxidative stress mechanism mediated through the necrotic pathway. In biological systems, ROS production and disturbances of cellular redox potentials have been found to be involved either directly or indirectly in the death of individual cells and/or the development of necrotic lesions (Pellinen et al., 2002; Yoda et al., 2006). Enhanced generation of ROS (hydrogen peroxide) and plasma membrane rupture have been traditionally associated with pathogenic events including necrotic cell death, which is recognized by morphological signs and is usually considered to be uncontrolled (Golstein \& Kroemer, 2007).

\section{Conclusion}

In summary, we showed that graphene exerted toxic effects on terrestrial plant species such as cabbage, tomato, and red spinach. The overproduction of ROS induced by graphene could be responsible for significant plant growth inhibition and biomass reduction 
compared to control. Nel et al., (2006) reported that the production of ROS can be a key factor in the toxicological effects of nanostructure materials. Observation of accumulation ROS production by means of $\mathrm{H}_{2} \mathrm{O}_{2}$ visualization along with visible signs of necrotic damage lesions and evidence of a massive electrolyte leakage all indicated an oxidative stress mechanism mediated through the necrotic pathway, which requires further study. We suggest an evaluation of graphene toxicity to targets on terrestrial plant species and applying a prolonged exposure period with different concentrations to measure any potential risk.
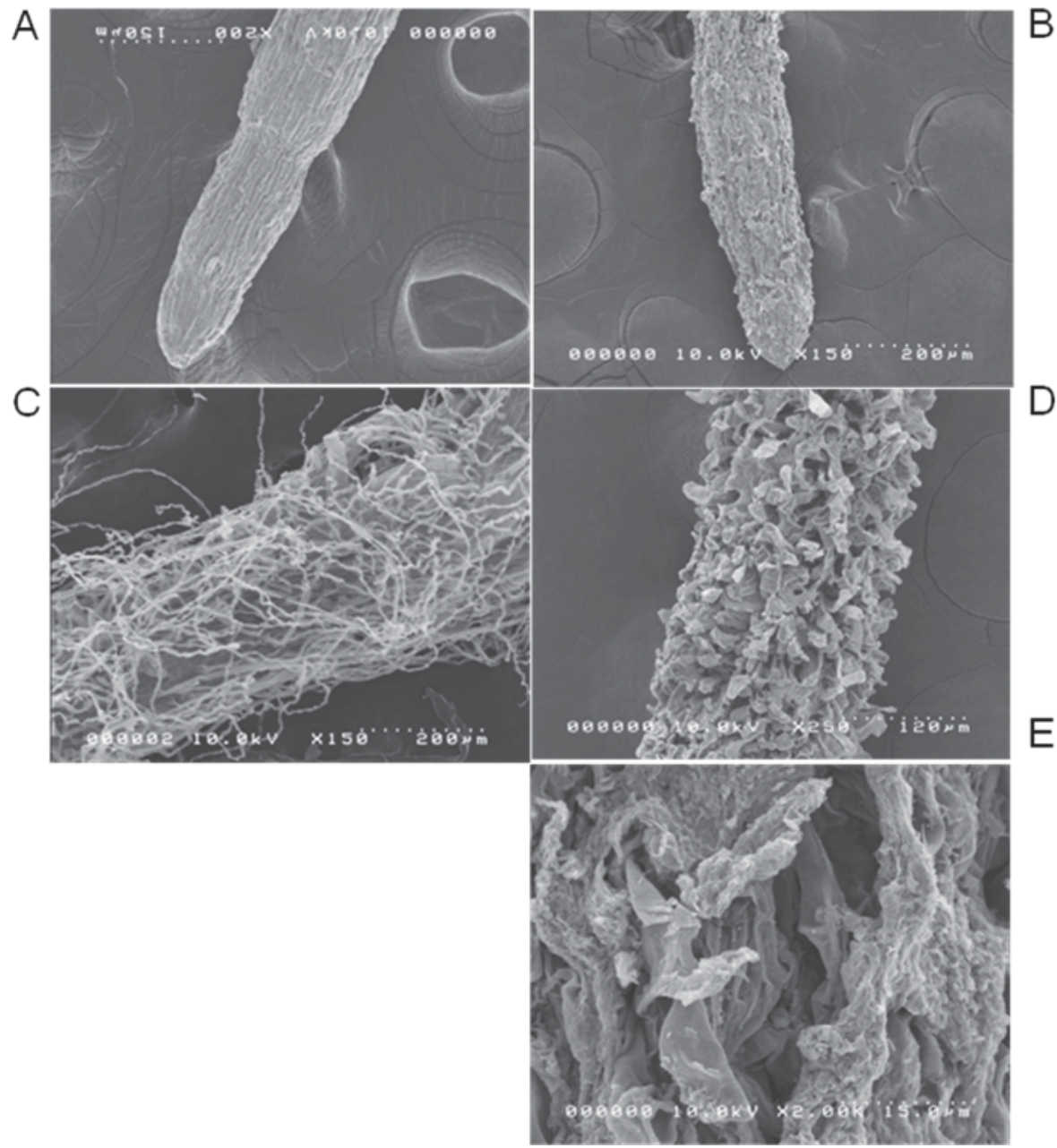

Fig. 11. Behavior of graphene $(1000 \mathrm{mg} / \mathrm{L})$ on the root surface of red spinach seedlings grown in Hoagland medium. (A, C) SEM image of the untreated control of red spinach root elongation, root hair zone and surface respectively. (B) Root elongation zone showing root damage (D) root hair zone and (E) surface showing aggregates of $G$ on the root of red spinach. 


\section{Materials and methods}

\subsection{Chemicals and seeds}

Chemicals used in this experiment were purchased from Kanto Chemical Co. Inc., Wako Pure Chemical Industries, Ltd., or Sigma Aldrich Inc., Japan. Seeds of three plant species (cabbage, Brassica oleracea var. capitata; tomato, Lycopersicon esculentum; and lettuce, Lactuca sativa) used in this study were purchased from Homac, Sapporo, Japan. Red spinach (Amaranthus tricolor L. and also Amaranthus lividus L.) seeds were purchased from Dhaka, Bangladesh.

\subsection{Preparation of water-soluble graphene}

Water-soluble graphene was obtained from natural graphite (SP-1, Bay Carbon) by using a modified Hummers and Offeman's method (Hummers \& Offeman, 1958). In a typical treatment, $100 \mathrm{~g}$ of the graphite powders and $50 \mathrm{~g}$ of sodium nitrate and $2000 \mathrm{~mL}$ sulfuric acid were mixed in an ice bath. Next, $100 \mathrm{~g}$ of potassium permanganate was slowly added and well mixed. Once mixed, the suspension was placed in a water bath at $35 \pm 3{ }^{\circ} \mathrm{C}$ and mixed for about $30 \mathrm{~min}$. About $5 \mathrm{~L}$ of deionized water was added to the suspension, the temperature was increased to $90 \pm 3{ }^{\circ} \mathrm{C}$, and the suspension was mixed further for about 30 min. The suspension was finally diluted to about $10 \mathrm{~L}$ with warm deionized water and about $200 \mathrm{~mL}$ of $30 \mathrm{wt} \% \mathrm{H}_{2} \mathrm{O}_{2}$. The warm suspension was filtered, and a yellow-brown filtered cake was obtained. The filtered cake was carefully washed with a large amount of warm deionized water and then dispersed in deionized water by mechanical mixing to prepare a stock graphene aqueous suspension containing approximately $2 \mathrm{wt} \%$ watersoluble graphene. An aqueous $0.1 \mathrm{~mol} / \mathrm{L}$ sodium hydroxide solution was used to neutralize the graphene solution to a $\mathrm{pH} 6.32$.

\subsection{Seedling exposure}

The sterile seeds of the selected plant species were soaked in solution with different concentrations $(0,500,1000$, and $2000 \mathrm{mg} / \mathrm{L})$ of graphene overnight at $25^{\circ} \mathrm{C}$ in the dark. Seeds were placed on wet filter paper and then exposed to $3 \mathrm{~mL}$ of the test solution with and without graphene and incubated at $25^{\circ} \mathrm{C}$ until germination. After germination, the number of germinated seeds was counted. The seedlings were transferred to plastic pots containing $200 \mathrm{~mL}$ Modified Hoagland Medium (Hoagland \& Arnon, 1950). Seedlings were treated with different concentrations of graphene solution (0, 500, 1000, or $2000 \mathrm{mg} / \mathrm{L})$. At 2000 $\mathrm{mg} / \mathrm{L}$ graphene was stable with very little settling.

\subsection{Root, shoot growth, and leaf characters}

After 20 days of exposure, roots and shoots were separated and washed with water to remove the growth medium and dried with wipes to remove the surface water. Their length and fresh weights were recorded. Leaf numbers were counted and leaf area measured using a RHIZO 2004b instrument.

\subsection{ROS measurements and $\mathrm{H}_{2} \mathrm{O}_{2}$ detection}

For visualization and measurement of ROS by spectroscopy, oxidatively sensitive probes DCFH-DA and DAB were used. Leaves of the treated and untreated plants were incubated in DCFH-DA for $2 \mathrm{~h}$. After three PBS rinses, the images for visualization were captured using fluorescence microscopy (Olympus IX70). We performed a measurement of DCFH 
fluorescence intensity in the leaves using a spectrofluorometer (Hitachi F-4500) by suspending the leaves in PBS buffer with an excitation wavelength at $485 \mathrm{~nm}$ and emission wavelength at $522 \mathrm{~nm}$. The values were expressed as \% of fluorescence intensity relative to control. This experiment was performed without exposure to light.

$\mathrm{H}_{2} \mathrm{O}_{2}$ was detected using DAB by the method previously described by Thordal-Christensen et al., (1997). The fresh leaves from 20-day-old treated and untreated plants were placed in 1 $\mathrm{mg} / \mathrm{mL}$ DAB-HCl, $\mathrm{pH} 3.2-3.8$ and incubated under vacuum for $\sim 8 \mathrm{~h}$. DAB deposits were revealed after washing leaves in boiled $100 \%$ (v/v) ethanol for $15 \mathrm{~min}$ to decolorize the leaves except for the deep brown polymerization product from the reaction of DAB with $\mathrm{H}_{2} \mathrm{O}_{2}$. The images were observed and recorded using light microscopy (Transmit Light Microscope BX51, With Olympus DP72 Camera). The amount of formazan formation in leaves was measured spectrophotometrically at $\mathrm{A}_{700}$ (V-530 UV/UISNIR Spectrophotometer, Jasco, Japan) after leaves were ground in liquid nitrogen and solubilized in a mixture of $2 \mathrm{M}$ $\mathrm{KOH}$ and DMSO at a ratio of 1:1.167 (v/v).

\subsection{Evaluation of cell death}

The cell death of the selected plant roots was evaluated by the method previously described by Baker \& Mock (1994) using Evans blue $(0.025 \% \mathrm{v} / \mathrm{v})$ for $2 \mathrm{~h}$ after 20 days of exposure to different concentrations $(0,500,1000$, and $2000 \mathrm{mg} / \mathrm{L})$ of graphene. For quantitative assessment, after several washes with water, the Evans blue was extracted using $1 \%(\mathrm{w} / \mathrm{v})$ SDS in $50 \%(\mathrm{v} / \mathrm{v})$ methanol at $50{ }^{\circ} \mathrm{C}$ for $15 \mathrm{~min}$, and the absorbance (optical density) was measured spectrophotometrically at $597 \mathrm{~nm}$ (V-530 UV/UISNIR Spectrophotometer, Jasco, Japan). Cell death was expressed as absorbance of treated roots in relation to untreated roots (control).

Cell death was also evaluated by measurement of ion leakage from leaf. The percent of injury of the membrane was measured from the electrolyte leakage of treated and untreated plants by a conductivity method based on the procedure of Lutts et al., (1996) with some modifications. Leaf samples $(100 \mathrm{mg}$ ) were placed in test tubes containing $10 \mathrm{~mL}$ of distilled water after three washes with distilled water to remove surface contamination. Test tubes were covered and incubated at room temperature $\left(25^{\circ} \mathrm{C}\right)$ on a shaker $(100 \mathrm{rpm})$ for $24 \mathrm{~h}$. Electrical conductivity of the solution $\left(\mathrm{L}_{\mathrm{t}}\right)$ was determined. Samples were then autoclaved at $120^{\circ} \mathrm{C}$ for $20 \mathrm{~min}$, and a final conductivity reading $\left(\mathrm{L}_{0}\right)$ was obtained upon equilibration at $25^{\circ} \mathrm{C}$. Electrolyte leakage was defined as: Electrolyte leakage $(\%)=\left(\mathrm{L}_{t} / \mathrm{L}_{0}\right) \times 100$. The extent of membrane injury (leakage of electrolytes) from cells was determined with a portable conductivity meter ( $\mathrm{pH} /$ Cond Meter, Horiba D-54).

\subsection{Morphological observation by AFM, SEM and TEM}

For AFM, an Agilent Series 5500 AFM instrument was used. The samples were prepared by casting a diluted aqueous graphene suspension on the surfaces of mica. The images were obtained using the tapping mode at a scanning rate of $1 \mathrm{~Hz}$. For SEM, a few drops of the graphene suspension were deposited on the aluminum stub, dried, sputter-coated, and observed using a Hitachi S-4000 SEM (Hitachi, Ibaraki, Japan) with an acceleration voltage of $10 \mathrm{kV}$. For SEM, the roots were fixed in $2.5 \%$ glutaraldehyde (GA) and $2 \%$ paraformaldehyde (PA) in $0.1 \mathrm{M}$ phosphate buffer (PB), $\mathrm{pH} 7.4$, postfixed in $1 \%$ osmium tetroxide, dehydrated, critical-point dried, sputter-coated, and observed. For TEM, the graphene nanosheets were homogeneously dispersed in 2-propanol under ultrasonication 
for $30 \mathrm{~min}$. A few drops of the suspension were deposited on the TEM grid covered with a Formvar membrane, dried, and evacuated before analysis. The preparations were observed using a Hitachi H-800 TEM. The acceleration voltage was $75 \mathrm{kV}$.

\subsection{Statistical analysis}

Each treatment was conducted in triplicate. Phytotoxicity endpoints for all measurements were compared to those of the unexposed controls. Statistical analysis was performed using the Student' $\mathrm{s}$ t-test. Values of P • 0.01 were considered significant. Data are presented as mean \pm SD (standard deviation).

\section{Acknowledgment}

We gratefully acknowledge Prof. Toru Mura and Prof. Shunitz Tanaka for providing necessary facilities during the study. We also gratefully acknowledge Yoshinobu Nodasaka and Natsumi Ushijima for their kind assistance in preparing the SEM and TEM samples. Many thanks go to Hongwen $\mathrm{Yu}$ for his assistance during the AFM study. The authors also wish to thank Mr. Egami Hiroshi for taking pictures of plant.

\section{References}

Akhavan, O. \& Ghaderi, E. (2010). Toxicity of Graphene and Graphene Oxide Nanowalls Against Bacteria. ACS Nano, Vol.4, No.10, pp.5731-5736, DOI 10.1021/nn101390x

Ando, T. (2009). The Electronic Properties of Graphene and Carbon Nanotubes. NPG Asia Materials, Vol.1, No.1, pp.17-21, ISSN 18844049

Apel, K. \& Hirt, H. (2004). Reactive Oxygen Species: Metabolism, Oxidative Stress, and Signal Transduction. Annual Review of Plant Biology, Vol.55, pp.373-399, DOI 10.1146/annurev.arplant.55.031903.141701

Baker, C.J. \& Mock, N.M. (1994). An Improved Method for Monitoring Cell Death in Cell Suspension and Leaf Disc Assays Using Evans Blue. Plant Cell, Tissue and Organ Culture, Vol.39, No.1, pp.7-12, ISSN 01676857

Bhabra, G.; Sood, A.; Fisher, B.; Cartwright, L.; Saunders, M.; Evans, W.H.; Surprenant, A.; Lopez-Castejon, G.; Mann, S.; Davis, S.A.; Hails, L.A.; Ingham, E.; Verkade, P.; Lane, J.; Heesom, K.; Newson, R. \& Case, C.P. (2009). Nanoparticles Can Cause DNA Damage Across a Cellular Barrier. Nature Nanotechnology, Vol.4, pp.876-883, DOI 10.1038/NNANO.2009.313

Breusegem, F.V. \& Dat, J.F. (2006). Reactive Oxygen Species in Plant Cell Death. Plant Physiology, Vol.141, No.2, pp.384-390, DOI 10.1104/pp.106.078295

Del Pozo, O. \& Lam, E. (1998). Caspases and Programmed Cell Death in The Hypersensitive Response of Plants to Pathogens. Current Biology, Vol.8, No.20, pp.1129-1132, DOI 10.1016/S0960-9822(98)70469-5

Dragoman, M. \& Dragoman, D. (2009). Graphene-based Quantum Electronics. Progress in Quantum Electronics, Vol.33, No.6, pp.165-214, DOI 10.1016/j.pquantelec. 2009.08.001

Enderlein, C.; Kim, Y.S.; Bostwick, A.; Rotenberg, E. \& Horn, K. (2010). The Formation of an Energy Gap in Graphene on Ruthenium by Controlling the Interface. New Journal of Physics, Vol.12, 033014 (9pp), DOI 10.1088/1367-2630/12/3/033014

Geim, A.K. \& Novoselov, K.S. (2007). The Rise of Graphene. Nature Materials, Vol.6, No.3, pp.183-191, ISSN 1476-1122 
Ghodake, G.; Seo, Y.D.; Park, D. \& Lee, D.S. (August 2010). Phytotoxicity of Carbon Nanotubes Assessed by Brassica Juncea and Phaseolus Mungo. Journal of Nanoelectronics and Optoelectronics, Vol.5, No.2, pp.157-160 (4), DOI 10.1166/jno.2010.1084

Golstein, P. \& Kroemer, G. (2007). Cell Death by Necrosis: Towards a Molecular Definition. Trends in Biochemical Sciences, Vol.32, No.1, pp.37-43, DOI 10.1016/j.tibs.2006.11.001

Hoagland, D.R. \& Arnon, D.I. (1950). The Water Culture Method for Growing Plants Without Soil. The College of Agriculture, University of California, California Agricultural Experiment Station Circular 347, Berkeley, pp. 1-32

Hummers, W.S.Jr. \& Offeman, R.E. (1958). Preparation of Graphitic Oxide. Journal of American Chemical Socceity, Vol.80, No.6, pp. 1339, DOI 10.1021/ja01539a017

Jia, G.; Wang, H.; Yan, L.; Wang, X.; Pei, R.; Yan, T.; Zhao, Y. \& Guo, X. (2005). Cytotoxicity of Carbon Nanomaterials: Single-Wall Nanotube, Multi-Wall Nanotube, and Fullerene. Environmental Science \& Technology, Vol.39, No.5, pp.1378-1383, DOI 10.1021/es0487291

Joseph, T., \& Morrison, M. (2006). Nanotechnology in Agriculture and Food. Available from www. nanoforum.org

Kawai-Yamada, M.; Ohori, Y. \& Uchimiya, H. (2004). Dissection of Arabidopsis Bax Inhibitor-1 Suppressing Bax-, Hydrogen Peroxide-, and Salicylic Acid-induced Cell Death. The Plant Cell, Vol.16, pp.21-32, DOI 10.1105/tpc.014613

Khodakovskaya, M.V.; Silvaa, K.de.; Nedosekinb, D.A.; Dervishic, E.; Birisa, A.S.; Shashkovb, E.V.; Galanzhab, E.I. \& Zharovb, V.P. (2011). Complex Genetic, Photothermal, and Photoacoustic Analysis of Nanoparticle-plant Interactions. Proceedings of the National Academy of Science (PNAS) Vol.108, No.3, pp.1028-1033, DOI 10.1073/pnas.1008856108

Kirchner, C.; Liedl, T.; Kudera, S.; Pellegrino, T.; Javier, A.M.; Gaub, H.E.; Stolzle, S.; Fertig, N. \& Parak, W.J. (2005). Cytotoxicity of Colloidal CdSe and CdSe/ZnS Nanoparticles. Nano Letters, Vol.5, No.2, pp.331-338, DOI 10.1021/nl047996m

Kopittke, P.M.; Asher, C.J.; Kopittke, R.A. \& Menzies, N.W. (2007). Toxic Effects of $\mathrm{Pb}^{2+}$ on Growth of Cowpea (Vigna unguiculata). Environmental Pollution, Vol.150, No.2, pp.280-287, ISSN 0269-7491

Lin, C.; Fugetsu, B.; Su, Y. \& Watari, F. (2009). Studies on Toxicity of Multi-Walled Carbon Nanotubes on Arabidopsis T87 Suspension Cells. Journal of Hazardous Materials, Vol.170, No.2-3, pp.578-583, DOI 10.1016/j.jhazmat.2009.05.025

Lin, D.H. \& Xing, B.S. (2007). Phytotoxicity of Nanoparticles: Inhibition of Seed Germination and Root Growth. Environmental Pollution, Vol.150, No.2, pp.243-250, DOI 10.1016/j.envpol.2007.01.016

Lin, S.; Reppert, J.; Hu, Q.; Hudson, J.A.S.; Reid, M.L.; Ratnikova, T.A.; Rao, A.M.; Luo, H. \& Ke, P.C. (2009). Uptake, Translocation, and Transmission of Carbon Nanomaterials in Rice Plants. Small, Vol.5, No.10, pp.1128-1132, DOI 10.1002/smll.200801556

Liu, Q.; Chen, B.; Wang, Q.; Shi, X.; Xiao, Z.; Lin, J. \& Fang, X. (2009). Carbon Nanotubes as Molecular Transporters for Walled Plant Cells. Nano Letter, Vol.9, No.3, pp.1007-1010, DOI $10.1021 / \mathrm{nl} 803083 \mathrm{u}$

Lui, C.H.; Liu, L.; Mak, K.F.; Flynn, G.W. \& Heinz, T.F. (2009). Ultraflat Graphene. Nature, Vol.462, pp.339-341, DOI 10.1038/nature08569

Lutts, S.; Kinet, J.M. \& Bouharmont, J. (1996). NaCl-Induced Senescence in Leaves of Rice (Oryza sativa L.) Cultivar Differing in Salinity Resistance. Annals of Botany (Lond), Vol.78, No.3, pp.389-398, DOI 10.1006/anbo.1996.0134 
Meyer, J.C.; Geim, A.K.; Katsnelson, M.I.; Novoselov, K.S.; Booth, T.J. \& Roth, S. (2007). The Structure of Suspended Graphene Sheets. Nature, Vol.446, No.7131, pp.60-63, DOI 10.1038 /nature05545

Monica, R.C. \& Cremonini, R. (2009). Nanoparticles and Higher Plants. Caryologia, Vol.62, No.2, pp.161-165, ISSN 0008-7114

Nel, A.; Xia, T.; Madler, L. \& Li, N. (2006). Toxic Potential of Materials at the Nanolevel. Science, Vol.311, No.5761, pp.622-627, DOI 10.1126/science.1114397

Nowack, B. \& Bucheli, T.D. (2007). Occurrence, Behavior and Effects of Nanoparticles in the Environment. Environmental Pollution, Vol.150, No.1, pp.5-22, DOI 10.1016/j.envpol.2007.06.006

Panou-Filotheou, H. \& Bosabalidis, A.M. (2004). Root Structural Aspects Associated with Copper Toxicity in Oregano (Origanum vulgare subsp. hirtum). Plant Science, Vol.166, No.6, pp.1497-1504, DOI 10.1016/j.plantsci.2004.01.026

Pellinen, R.I.; Korhonen, M.S.; Tauriainen, A.A.; Palva, E.T. \& Kangasjärvi, J. (2002). Hydrogen Peroxide Activates Cell Death and Defense Gene Expression in Birch, Plant Physiology, Vol.130, pp.549-560, DOI 10.1104/pp.003954

Sayes, C.M.; Liang, F.; Hudson, J.L.; Mendez, J.; Guo, W.; Beach, J.M.; Moore, V.C.; Doyle, C.D.; West, J.L.; Billups, W.E.; Ausman, K.D. \& Colvin, V.L. (2006). Functionalization Density Dependence of Single-Walled Carbon Nanotubes Cytotoxicity in Vitro. Toxicological Letter, Vo.161, pp.135-142, DOI 10.1016/j.toxlet.2005.08.011

Stampoulis, D.; Sinha, S.K. \& White, J.C. (2009). Assay-Dependent Phytotoxicity of Nanoparticles to Plants. Environmental Science \& Technology, Vol.43, No.24, pp.94739479, ISSN 0013-936X

Stankovich, S.; Dikin, D.A.; Dommett, G.H.B.; Kohlhaas, K.M.; Zimney, E.J.; Stach, E.A.; Piner, R.D.; Nguyen, S.T. \& Ruoff, R.S. (2006). Graphene-based Composite Materials. Nature, Vol.442, No.7100, pp.282-286, DOI 10.1038/nature04969

Stiles, W. (1961). Trace Elements in Plants, 3rd ed. Cambridge University Press, London. pp. 249

Tan, X.M.; Lin, C. \& Fugetsu, B. (2009). Studies on Toxicity of Multi-Walled Carbon Nanotubes on Suspension Rice Cells. Carbon, Vol.47, No.15, pp.3479-3487, DOI 10.1016/j.carbon.2009.08.018

Thordal-Christensen, H.; Zhang, Z.; Wei, Y. \& Collinge, D.B. (1997). Subcellular Localization of $\mathrm{H}_{2} \mathrm{O}_{2}$ in Plants. $\mathrm{H}_{2} \mathrm{O}_{2}$ Accumulation in Papillae and Hypersensitive Response During the Barley-Powdery Mildew Interaction. The Plant Journal, Vo.11, No.6, pp.1187-1194, ISSN 0960-7412

USEPA-Ecological Effects Test Guidelines (OPPTS 850.4200) (1996). Seed Germination Root Elongation Toxicity Test. Available from: http://www.epa.gov/publications

Wen, F.; Xing, D. \& Zhang, L.R. (2008). Hydrogen Peroxide is Involved in High Blue LightInduced Chloroplast Avoidance Movements in Arabidopsis. Journal of Experimental Botany, Vol.59, No.10, pp.2891-2901, DOI 10.1093/jxb/ern147

Xia, J.; Chen, F.; Li, J. \& Tao, N. (2009). Measurement of the Quantum Capacitance of Graphene. Nature Nanotechnology, Vol.4, pp. 505-509, DOI 10.1038/nnano.2009.177

Yoda, H.; Yamaguchi, Y. \& Sano, H. (2006). Polyamine Oxidase is One of the Key Elements for Oxidative Burst to Induce Programmed Cell death in Tobacco Cultured Cells, Plant Physiology, Vol.142, pp.193-206, DOI 10.1104/pp.106.080515

Zhang, Y.; Ali, S.F.; Dervishi, E.; Xu, Yang.; Li, Z.; Casciano, D. \& Biris, A.S. (2010). Cytotoxicity Effects of Graphene and Single-Wall Carbon Nanotubes in Neural Phaeochromocytoma-Derived PC12 Cells. ACS Nano, Vol.4, No.6, pp.3181-3186, DOI 10.1021/nn1007176 


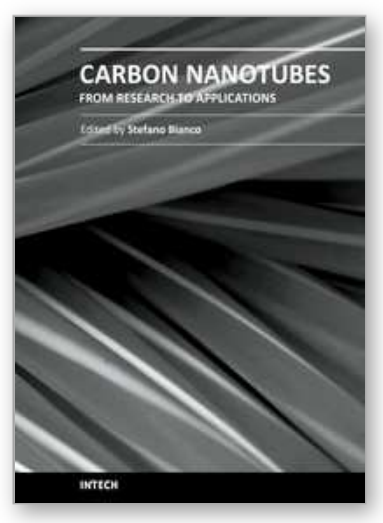

\author{
Carbon Nanotubes - From Research to Applications \\ Edited by Dr. Stefano Bianco
}

ISBN 978-953-307-500-6

Hard cover, 358 pages

Publisher InTech

Published online 20, July, 2011

Published in print edition July, 2011

Since their discovery in 1991, carbon nanotubes have been considered as one of the most promising materials for a wide range of applications, in virtue of their outstanding properties. During the last two decades, both single-walled and multi-walled CNTs probably represented the hottest research topic concerning materials science, equally from a fundamental and from an applicative point of view. There is a prevailing opinion among the research community that CNTs are now ready for application in everyday world. This book provides an (obviously not exhaustive) overview on some of the amazing possible applications of CNT-based materials in the near future.

\title{
How to reference
}

In order to correctly reference this scholarly work, feel free to copy and paste the following:

Fugetsu and Parvin Begum (2011). Graphene phytotoxicity in the seedling stage of cabbage, tomato, red spinach, and lettuce, Carbon Nanotubes - From Research to Applications, Dr. Stefano Bianco (Ed.), ISBN: 978-953-307-500-6, InTech, Available from: http://www.intechopen.com/books/carbon-nanotubes-fromresearch-to-applications/graphene-phytotoxicity-in-the-seedling-stage-of-cabbage-tomato-red-spinach-andlettuce

\section{INTECH}

open science | open minds

\section{InTech Europe}

University Campus STeP Ri

Slavka Krautzeka 83/A

51000 Rijeka, Croatia

Phone: +385 (51) 770447

Fax: +385 (51) 686166

www.intechopen.com

\section{InTech China}

Unit 405, Office Block, Hotel Equatorial Shanghai

No.65, Yan An Road (West), Shanghai, 200040, China 中国上海市延安西路65号上海国际贵都大饭店办公楼405单元

Phone: +86-21-62489820

Fax: +86-21-62489821 
(C) 2011 The Author(s). Licensee IntechOpen. This chapter is distributed under the terms of the Creative Commons Attribution-NonCommercialShareAlike-3.0 License, which permits use, distribution and reproduction for non-commercial purposes, provided the original is properly cited and derivative works building on this content are distributed under the same license. 